\title{
HIV Transcription is Induced with Some Forms of Cell killing
}

\begin{abstract}
Gayle E. Woloschak, 1,* Steven Schreck, ${ }^{1,4}$ John Panozzo,2 Chin-Mei Chang-Liu, ${ }^{1}$ and Claudia R. Libertin ${ }^{2,3}$
\end{abstract}

${ }^{1}$ Center for Mechanistic Biology and Biotechnology Argonne National Laboratory 9700 South Cass Avenue Argonnne, IL 60439-4833

${ }^{2}$ Department of Pathology, ${ }^{3}$ Department of Medicine Loyola University Medical Center

2160 South First Avenue

Maywood, IL 60153

${ }^{4}$ Current address: Dept. Chemistry, Univ. of South Carolina, Columbia, SC 29208

*Corresponding author's telephone: (708)252-3312

fax: $(708) 252-3387$

Running Head: Cell killing induces HIV 


\section{DISCLAIMER}

Portions of this document may be illegible in electronic image products. Images are produced from the best available original document. 


\begin{abstract}
Using HeLa cells stably transfected with an HIV-LTR-CAT

construct, we demonstrated a peak in CAT induction that occurs in viable (but not necessarily cell-division-competent) cells $24 \mathrm{~h}$ following exposure to some cell-killing agents. $\gamma$ rays were the only cell-killing agent which did not induce HIV transcription; this can be attributed to the fact that $\gamma$-ray-induced apoptotic death requires function p53, which is missing in Hela cells. For all other agents, HIV-LTR induction was dose-dependent and correlated with the amount of cell killing that occurred in the culture.
\end{abstract}

\title{
DISCLAIMER
}

This report was prepared as an account of work sponsored by an agency of the United States Government. Neither the United States Government nor any agency thereof, nor any of their employees, makes any warranty, express or implied, or assumes any legal liability or responsibility for the accuracy, completeness, or usefulness of any information, apparatus, product, or process disclosed, or represents that its use would not infringe privately owned rights. Reference herein to any specific commercial product, process, or service by trade name, trademark, manufacturer, or otherwise does not necessarily constitute or imply its endorsement, recommendation, or favoring by the United States Government or any agency thereof. The views and opinions of authors expressed herein do not necessarily state or reflect those of the United States Government or any agency thereof. 


\section{INTRODUCTION}

Valerie et al. (9) described the induction of transcription from the human immunodeficiency virus long terminal repeat (HIVLTR) following exposure to DNA-damaging agents in HeLa cells stably transfected with a construct containing the chloramphenicol acetyl transferase (CAT) reporter gene driven by the HIV-LTR promoter. Since then, many reports have reproduced and expanded upon those findings $(5,10-13)$, even demonstrating in vivo induction in transgenic mouse systems. Recent work from our laboratory has shown enhanced expression from the HIV promoter following exposure of cells to fission-spectrum neutrons at doses which also induce expression of apoptosis-associated genes (10). We set out in these experiments to determine whether this HIV-LTR induction was a consequence of DNA damage, as suggested by the initial reports, or whether it was associated with the onset of cell death in general (such as occurs during apoptosis or programmed cell death).

\section{MATERIALS AND METHODS}

Cell lines. HeLa cells stably transfected with HIV-LTR-CAT construct were generously provided by Dr. K. Valerie (10). Immediate cell death was determined by trypan blue dye exclusion. Colony forming cell assays (14 day) were performed as described $(3,11)$ 
CAT assays. CAT assays were performed as previously desribed $(3,11)$.

Treatments. Equal numbers and concentrations of HeLa cells stably transfected with the HIV-LTR-CAT construct were exposed in triplicate to varying doses of electric current at the indicated voltages; electroporation was carried out in the presence of PBS. Cells were harvested $24 \mathrm{~h}$ following exposure and counted.

For UV exposures, HeLa cells stably transfected with the HIV-LTR-CAT construct were exposed to different doses (as indicated) of UVC (254 nm) germicidal lamp. Cells were harvested 24-180 h following exposure. Equal numbers of viable cells were used in each CAT assay $(3,11)$. Conditions for other treatments are as defined in Table 1 and as defined $(3,11)$.

\section{RESULTS}

Figure 1 details the results of experiments examining the effects of electroporation of sucrose buffer on the induction of CAT expression driven by HIV-LTR. In these experiments, cells were exposed to differing electric voltage levels $(0.1$ or $0.3 \mathrm{kV})$ in phosphate-buffered sucrose. At the same time, each culture

was monitored for the number of total viable cells when the total number of input cells for each experimental group was the same. These results demonstrated maximal induction of the LTR-CAT 
construct at voltages which resulted in maximal cell killing. It should be noted that equal numbers of viable cells only were used for each CAT assay so as to avoid variation caused by the number of dead cells resulting from the treatment conditions. These and all other results are from a single experiment since cpm are not directly comparable from one experiment to the next; all results have been repeated twice after the original observation to confirm validity.

Next, the effects of UV exposure on expression of the CAT reporter gene were examined; Fig. 2 shows results demonstrating induction of CAT following UV exposure. The response peaked at $24 \mathrm{~h}$ following exposure and was maintained at high levels even as late as $72 \mathrm{~h}$ following exposure; conditions were such that cell death was induced. Again, it should be noted that in these experiments, equal numbers of viable cells were used in determining the number of cells to be used in each CAT assay. The fact that this response remains high in those cultures in which cell death had been triggered, but not in sublethally treated cultures, further supports the concept that induction of HIV-LTR is associated with cell death rather than with DNA damage.

Figure 3 demonstrates the results of experiments examining UV effects on both colony formation (14-day assay) and CAT expression in the same cell cultures. Cellular colony formation was used as a measure of cell division/propagation capability. These experiments demonstrate a correlative relationship between 
HIV-LTR-mediated CAT expression and the lack of cell survival following UV exposure, i.e., cells that are not able to go on to divide express higher levels of LTR-CAT than those that do go on to divide. Fig. 4 similarly examines the effects of multiple UV doses on HIV-LTR-CAT induction. Exposures of $5 \mathrm{~J} / \mathrm{m}^{2}$ were not additive, and a dose between 5 and $20 \mathrm{~J} / \mathrm{m}^{2}$ was required for induction of HIV-LTR. These results suggest that HIV-LTR has a threshold UV dose for induction of CAT and that this threshold dose corresponds to a dose at which cell killing is first detectable in these cultures.

Table 1 summarizes the results of a series of results from our own published experiments $(3,11)$ in which various agents were tested under different conditions for their abilities to induce HIV-LTR-CAT expression. These experiments demonstrated that treatments which reduced cell viability also induced CAT expression. Treatments which induced HIV-LTR-mediated CAT expression included low pH (6.4), high pH (8.4), electroporation, UV exposure, and excess heat $1700 \mathrm{~W}$ [microwave] for $10 \mathrm{~s}$ in a small volume of PBS). On the other hand, treatments which had no effect on viability and no effect on HIV-LTR-CAT induction included co-culture with metronidazole (a DNA-damage-inducing drug), vitamin $C$ treatment, microwave exposure in an excess volume of medium to reduce overheating, exposure to electromagnetic fields, and heat-shock $\left(10 \mathrm{~min}\right.$ at $43^{\circ} \mathrm{C}, 2 \mathrm{~h}$ at $39^{\circ} \mathrm{C}$ ). Other work from our group has documented a failure to 
induce HIV following $\gamma$-ray exposure. This suggests that not all methods of inducing cell death are efficient in inducing HIV.

\section{DIscussion}

These results suggest a potentially causative association between some forms of cell killing and the induction of HIV expression. Past work has shown the requirement for new protein synthesis for induction of HIV (7). We hypothesize that one pathway for inducing cellular death (apoptosis or programmed cell death), which also requires new protein synthesis 2.61 , causes induction of HIV expression. The fact that this ponse is not repressed within the first $72 \mathrm{~h}$ following UV expo e (Fig. 2) suggests that the HIV inductive response is not $c$ ble of being directly repressed by the dying cell. We propose model whereby HIV lays dormant in cellular DNA until apoptosis cell death is naturally induced; this activation of apoptosis then turns on HIV expression so that maximal viral transcription occurs in apoptotic cells. Much work has demonstrated a relationship between HIV and apoptosis $(2,4,7)$, with most observations suggesting that HIV itself induces the apoptotic process. Our cell system does not produce active virus, so we cannot examine the possibility that HIV itself induces apoptosis, as shown by others $(2,4,7)$. Our data suggest, however, that the cell death/apoptotic response induces HIV. This could explain why HIV 
is expressed in vivo most commonly in $T$ cells which undergo natural developmental apoptosis in adults.

Finally, past work has suggested that UV-induced HIV transcription is mediated directly by DNA damage (7). Our model proposes that one mechanism by which HIV is induced is as a consequence of a cell death response; this response can be induced by a variety of agents, including those which damage DNA (UV, neutrons), those which denature proteins (excess heat; pH variations), and those which disrupt cell signaling (electroporation). The actual intracellular signal that induces programmed cell death responses is not known but may provide important insights for studies of HIV gene regulation. It is interesting that $\gamma$-rays have no effect on HIV expression in HeLa cells, a cell line which does not induce functional p53 protein following $\gamma$-ray exposure due to presence of the papillomavirus protein E6. HIV induction may be associated with a p53-dependent pathway of cell death/apoptosis.

\section{ACKNOWLEDGEMENTS}

The authors wish to thank Kay Bexson for excellent secretarial assistance and Gordon Holmblad for assistance in irradiations.

Work supported by the U.S. Department of Energy, Office of Health and Environmental Research, under Contract No. W-31-109ENG-38. 


\section{REFERENCES}

1. Inouye, M., Tamaru, M., and Kameyama, Y. (1992). Effects of cycloheximide and actinomycin $D$ on radiation-induced apoptotic cell death in the developing mouse cerebellum. Int. J. Radiat. Biol. 61, 669-674.

2. Laurent, A. G., Krust, B., Muller, S., Riviere, Y., ReyCuille, M-A., Bechet, J-M., Montagnier, L., and Hovanessian, A. G. (1991). The cytopathic effect of HIV is associated with apoptosis. Virology 185, 829-839.

3. Libertin, C. R., Panozzo, J., Groh, K., Chang-Liu, C-M., Schreck, S., and Woloschak, G. E. Effects of gamma rays, ultraviolet radiation, sunlight, microwaves, and electromagnetic fields on gene expression mediated by human immunodeficiency virus promoter. Radiat. Res., in press.

4. Meyaard, L., Otto, S. A., Jonker, R. R., Mijnster, M. J., Keet, R. P. M., and Miedema, F. (1992). Programmed death of $\mathrm{T}$ cells in HIV-1 infection. Science 257, 217-219.

5. Morrey, J. D., Bourn, S. M., Bunch, T. D., Jackson, M. K., Sidwell, R. W., Barrows, L. R., Daynes, R. A., and Rosen, C. A. (1991). In vivo activation of human immunodeficiency 
virus type 1 long terminal repeat by UV type A (UVA) light plus psoralen and UVB light in the skin of transgenic mice. J. Virol. 65, 5045-5051.

6. Sellins, K. S., and Cohen, J. J. (1987). Gene induction by $\boldsymbol{\gamma}$-irradiation leads to DNA fragmentation in lymphocytes. J. Immunol. 139, 3199-3206.

7. Stein, B., Kramer, M., Rahmsdorf, H. J., Ponta, H., and Herrlich, P. (1989). UV-induced transcription from the human immunodeficiency virus type 1 (HIV) long terminal repeat and UV-induced secretion of an extracellular factor that induces HIV-a transcription in irradiated cells. $J$. Virol. 63, 4540-4544.

8. Terai, C., Kornbluth, R. S, Pauza, C. D., Richman, D. D., and Carson, D. A. (1991). Apoptosis as a mechanism of cell death in cultured $T$ lymphoblasts acutely infected with HIV-1. J. Clin. Invest. 87, 1710-1715.

9. Valerie, K., Delers, A., Bruck, C., Thiriart, C., Rosenberg, H., Debouck, C., and Rosenberg, M. (1988). Activation of human immunodeficiency virus type 1 by DNA damage in human cells. Nature 333, 78-81. 
10. Valerie. K., and Rosenberg, M. (1990). Chromatin structure implicated in activation of HIV-1 gene expression by ultraviolet 1ight. New Biology 2, 712-718.

11. Woloschak, G.E., Chang-Liu, C-M., Panozzo, J., and Libertin, C. R. (1994). Low doses of neutrons induce changes in gene expression. Radiat. Res. 138, S56-S59.

12. Yamagol, S., Kohda, T., and Oishi, M. (1991). Poly (ADPribose) polymerase inhibitors suppress UV-induced human immunodeficiency virus type $i$ gene expression at the post transcriptional level. Molec. Cell. Biol. 11, 3522-3527.

13. Zmudzka, B. Z., and Beer, J. Z. (1990). Activation of human immunodeficiency virus by ultraviolet radiation. Photochem. Photobiol. 52, 1153-1162. 
TABLE 1. Effects of Various Agents on HIV-LTR-CAT Induction

\begin{tabular}{|c|c|c|}
\hline Agent & $\begin{array}{l}\text { Fold HIV-LTR- } \\
\text { CAT Induction }\end{array}$ & $\begin{array}{l}\text { No. } \\
\text { Experiments }\end{array}$ \\
\hline No treatment & 1.0 & $>20$ \\
\hline $\mathrm{pH} 6.7-8.1$ & $0.7-1.0$ & 3 \\
\hline $\mathrm{pH} 6.4$ & $1 \cdot 5-2 \cdot 0^{b}$ & 2 \\
\hline $\mathrm{pH} 8.4$ & $1 \cdot 6-2 \cdot 0^{\mathrm{b}}$ & 3 \\
\hline $\begin{array}{l}\text { Microwaves }(700 \mathrm{~W}), 5-12 \mathrm{~s}, 25 \mathrm{ml} \\
\left.\mathrm{PBS} / \text { pen/strep (temp. } \angle 43^{\circ} \mathrm{C}\right)\end{array}$ & $0.8-1.1$ & 4 \\
\hline $\begin{array}{l}\text { Microwaves }(700 \mathrm{~W}), 10 \mathrm{~s}, 10 \mathrm{ml} \\
\left.\text { PBS/pen/strep (temp. } \angle 43^{\circ} \mathrm{C}\right)\end{array}$ & $2 \cdot 2-2 \cdot 5^{b}$ & 4 \\
\hline Electromagnetic radiation $(60 \mathrm{~Hz})$ & $1.0-1.2$ & 4 \\
\hline Ultraviolet radiation $\left(\geq 5 \mathrm{~J} / \mathrm{m}^{2}\right)$ & $2 \cdot 0-29 \cdot 2^{b}$ & $>20$ \\
\hline Ultraviolet radiation $\left(<2.5 \mathrm{~J} / \mathrm{m}^{2}\right)$ & $1.0-1.3$ & $>20$ \\
\hline Vitamin $C(0.1-1.0 \mathrm{mg} / \mathrm{ml})$ & $0.8-1.2$ & 2 \\
\hline Metronidazole $(6-12 \mu \mathrm{g} / \mathrm{ml})$ & $0.8-1.3$ & 2 \\
\hline $\begin{array}{l}\text { Electroporation of buffered } \\
\text { sucrose }(0.1-0.3 \mathrm{kV})\end{array}$ & $3.7-36.1^{b}$ & 3 \\
\hline $\begin{array}{l}\text { Heat shock }\left(38-45^{\circ} \mathrm{C}, 10 \mathrm{~min}\right. \\
\left.39^{\circ} \mathrm{C}, 2 \mathrm{~h}\right)\end{array}$ & $0.7-1.1$ & 3 \\
\hline $\begin{array}{l}\text { Fission-spectrum neutrons } \\
(48 \mathrm{CGy})\end{array}$ & $1 \cdot 2-2 \cdot 0^{b}$ & 3 \\
\hline Solar radiation $\left(240 \mathrm{KJ} / \mathrm{m}^{2}\right)$ & $1.0-1.3$ & 3 \\
\hline
\end{tabular}

${ }^{a}$ All measurements 12-24 h following exposure

${ }^{\mathrm{b}}$ Significantly different from controls at $\underline{p}<.01$ 


\section{Figure Legends}

Figure 1. A: Cell survival documents the numbers of viable cells remaining in the culture as determined by trypan blue dye exclusion at the time of cell harvest. The number atop each column indicates the percentage of viable cells remaining in the culture. B: Equal numbers of viable cells were counted and used in the CAT assays for the ${ }^{3} \mathrm{H}$ acetylation of chloramphenicol. Assays were performed as described previously (10).

Figure 2. HeLa cells stably transfected with the HIV-LTR-CAT construct were exposed to different doses (as indicated) of UVC (254 nm) germicidal lamp. Cells were harvested 24-180 h following exposure. Equal numbers of viable cells were used in each CAT assay (10). At the high dose $\left(25 \mathrm{~J} / \mathrm{m}^{2}\right)$, there were no viable cells remaining for assay after $96 \mathrm{~h}$ post-exposure.

Figure 3. HeLa cells stably transfected with HIV-LTR-CAT construct were exposed to doses $\left(\mathrm{J} / \mathrm{m}^{2}\right)$ as indicated of UVC (254 nm) germicidal lamp. From each culture, an equal number of cells for each treatment were used for 14-day colony assays for cell survival determination ( $A$; expressed as the number of colonies/number of cells plated $\times 100$ ) and equal numbers of viable cells were set up in CAT assays for expression studies (B; 10). 
Figure 4. HeLa cells stably transfected with HIV-LTR-CAT were exposed at $24-\mathrm{h}$ intervals to 0,5 or $10 \mathrm{Jm}^{-2}$ UVC $(254 \mathrm{~nm})$ germicidal lamp. Cells were harvested at $24 \mathrm{~h}$ and $48 \mathrm{~h}$ postexposure. Equal numbers of viable cells were used for CAT assays as described (10). 


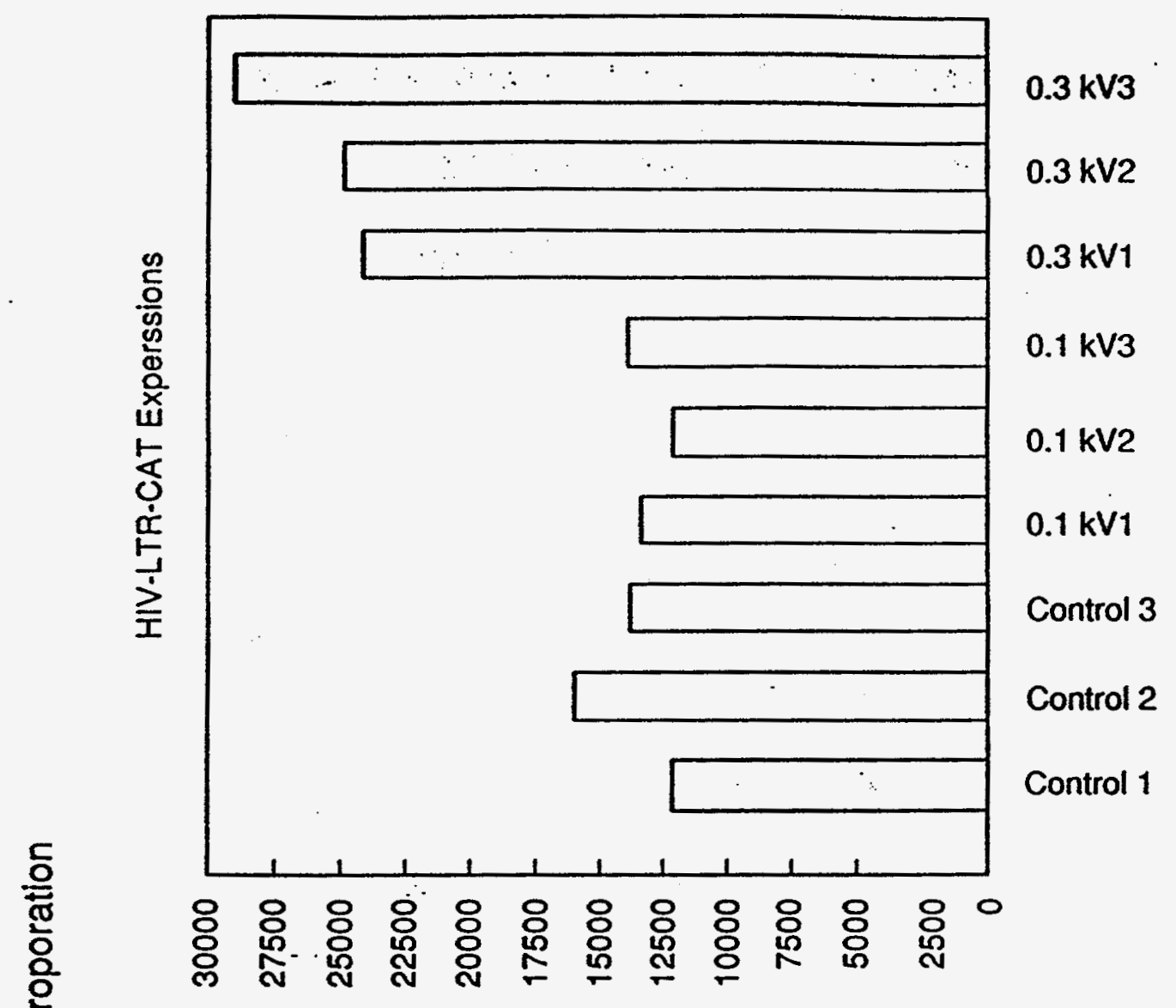

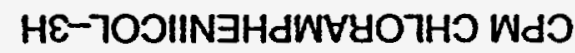

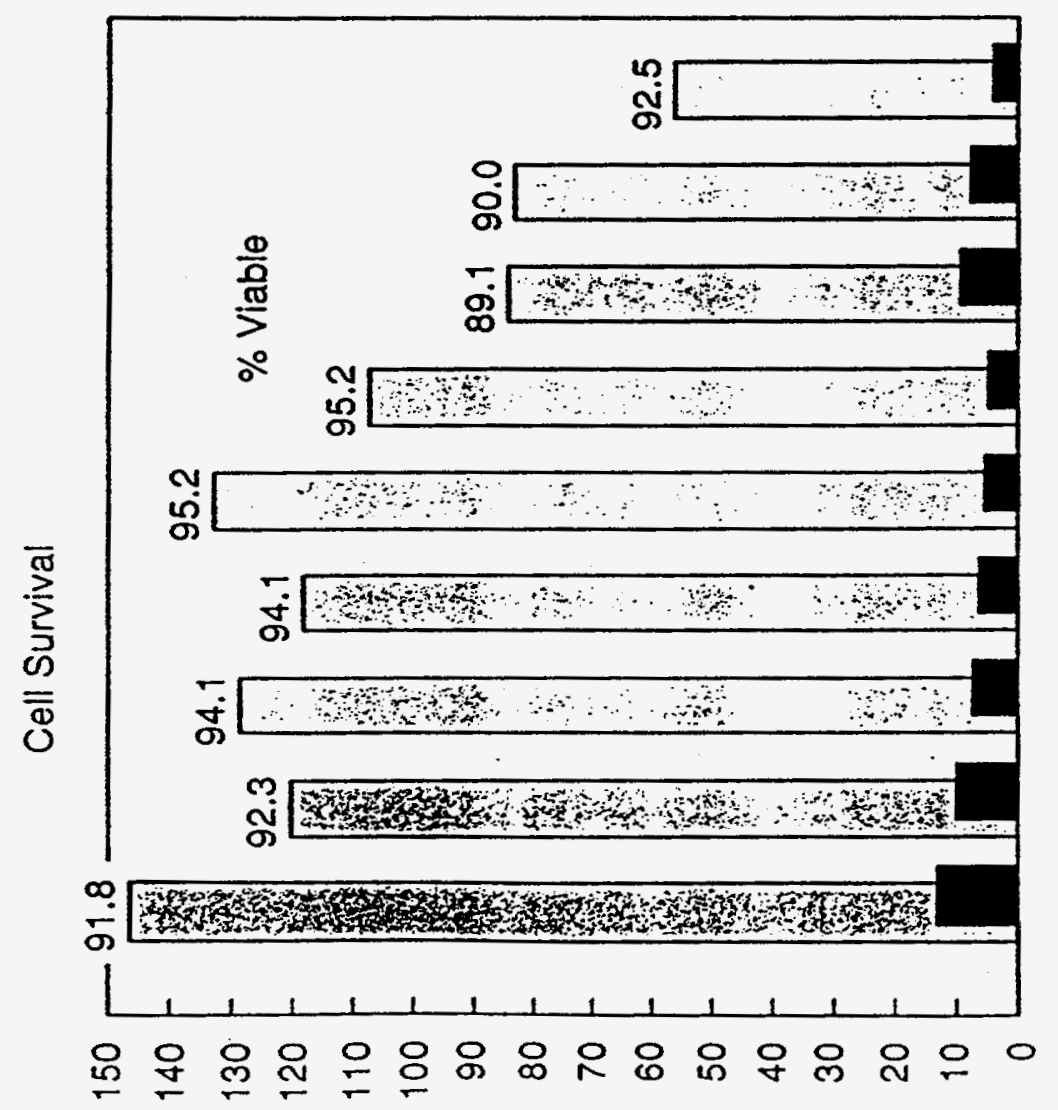

$0.3 \mathrm{kV} 3$

$0.3 k V 2$

$0.3 \mathrm{kV} 1$

$\stackrel{9}{\overline{0}}$

$0.1 \mathrm{kV} 3$

존전

$0.1 \mathrm{kV} 2$

$0.1 \mathrm{kV} 1$

胥

ติ

Control 3 ฐี జิ

돈흔

Control 2

Control 1 


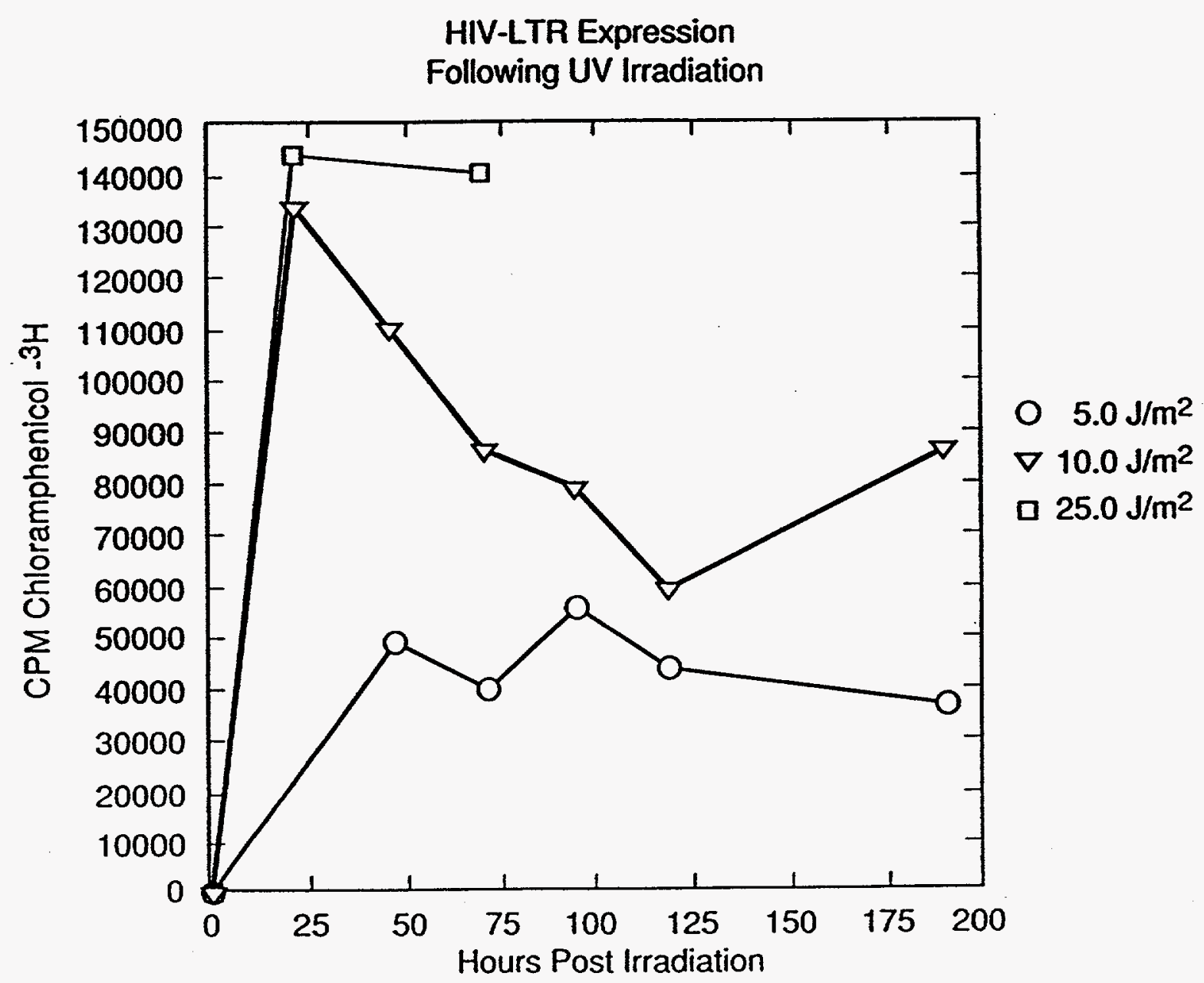




\section{Effects of UV}

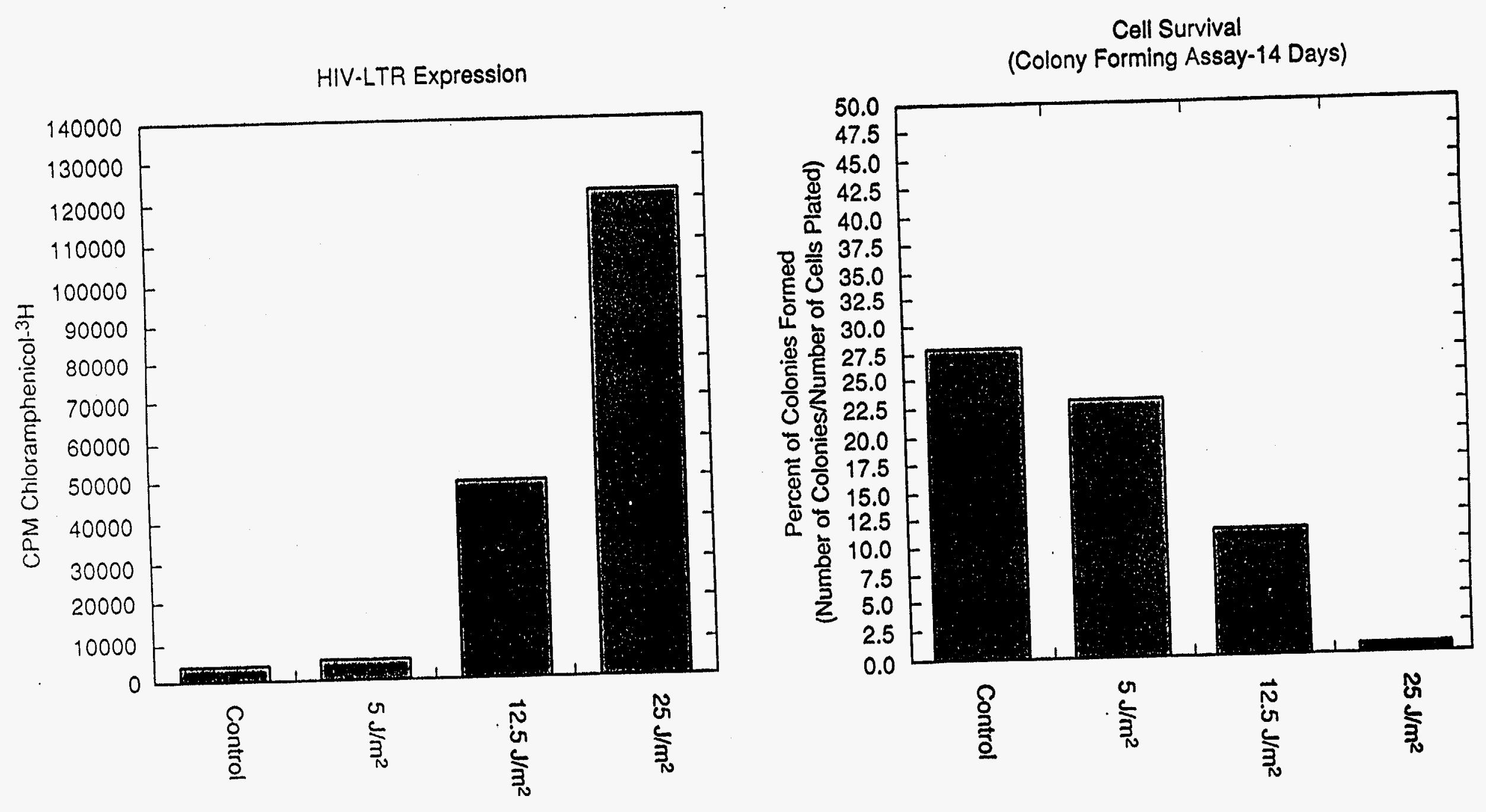


Effects of Ultraviolet Radiation on HIV-LTR Expression

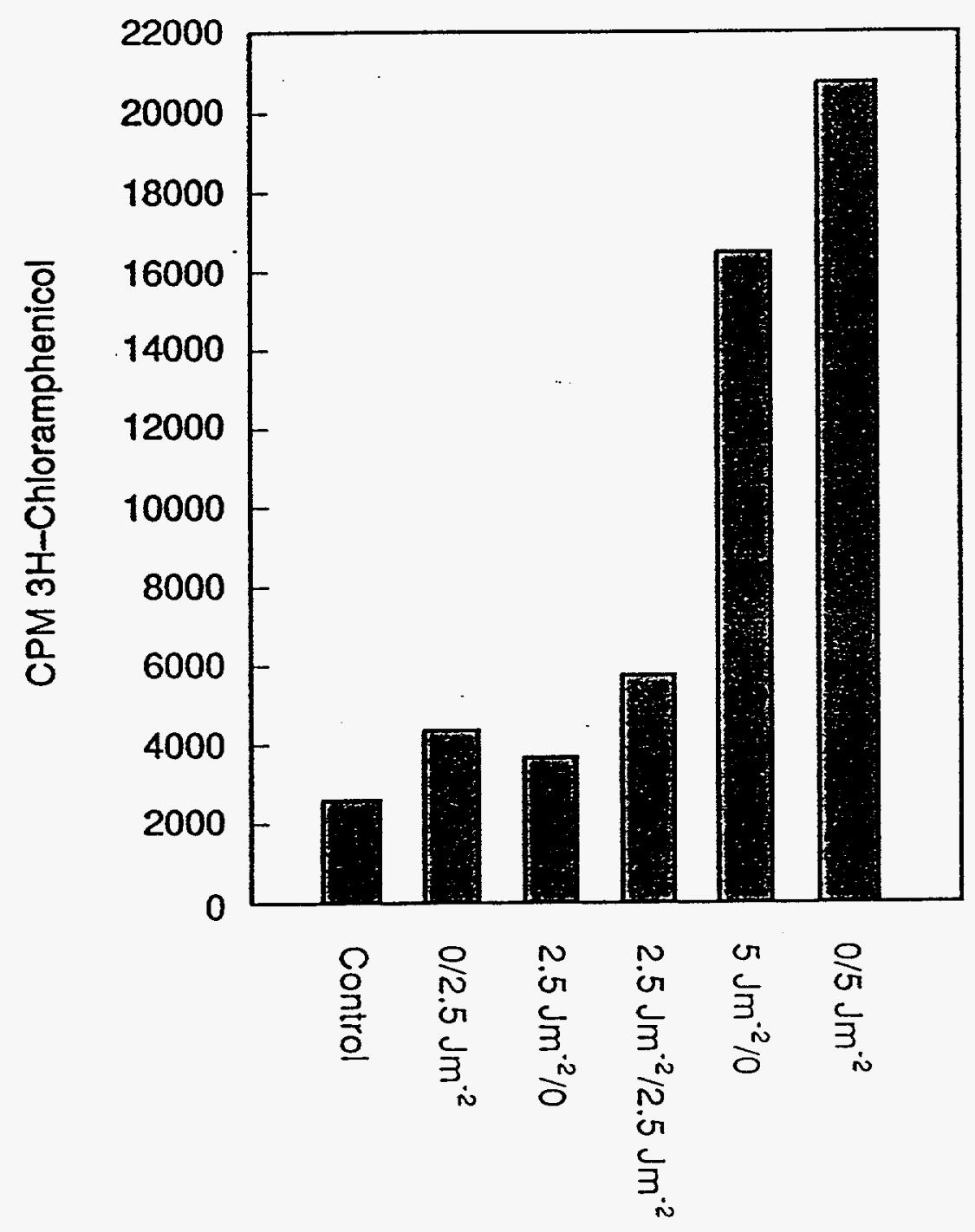

